University for Business and Technology in Kosovo

UBT Knowledge Center

Oct 27th, 3:00 PM - 4:30 PM

\title{
Importance of adequate monetary policy in time dynamic of being a new member of European Union - case of Republic of Serbia
}

Zenaida Šabotić

State University of Novi Pazar, zsabotic@np.ac.rs

Follow this and additional works at: https://knowledgecenter.ubt-uni.net/conference

Part of the Business Commons

\section{Recommended Citation}

Šabotić, Zenaida, "Importance of adequate monetary policy in time dynamic of being a new member of European Union - case of Republic of Serbia" (2017). UBT International Conference. 241.

https://knowledgecenter.ubt-uni.net/conference/2017/all-events/241

This Event is brought to you for free and open access by the Publication and Journals at UBT Knowledge Center. It has been accepted for inclusion in UBT International Conference by an authorized administrator of UBT Knowledge Center. For more information, please contact knowledge.center@ubt-uni.net. 


\title{
Importance of adequate monetary policy in time dynamic of being a new member of European Union - case of Republic of Serbia
}

\author{
Zenaida Šabotić ${ }^{1}$ \\ ${ }^{1}$ State University of Novi Pazar, Department of Economics Sciences \\ 36300 Novi Pazar, Vuka Karadžića bb, Republic of Serbia \\ zsabotic@np.ac.rs
}

\begin{abstract}
In order to became a new European Union (EU) member, many countries have subordinated own monetary policy and accepted main objectives of EU monetary policy. Although, it is quite clear that the defined goals and instruments of EU monetary policy can not equally match the national objectives of the member countries, there is a common view that unique monetary policy has more advantages than disadvantages. For those countries that are in the negotiation process, the time period of harmonisation of monetary policy and realisation of the set goals is very important. That dynamic is more important than formal time of accession to the EU. This paper explore monetary policy in Serbia, with reference to the main macroeconomic indicators, in order to determine the optimal moment of Serbia's accession to the EU from the economic aspect, i.e. reaching the numerical values of key macroeconomic data singled out as the most important indicators in this process.
\end{abstract}

Keywords: European Union, monetary policy, macroeconomic indicators, Republic of Serbia

\section{Introduction}

Monetary policy is an effective way for the monetary authorities of a country to solve problems as well as internal and external imbalances. The success in realising the set monetary policy objectives depends on a large number of factors, which have their foothold in both monetary and real factors. The time period in which the effects of the implemented policy are manifested is from 20 to 24 months. Within this period, depending on the activities of all economic entities, this process may be slowed down or accelerated. Thus, the monetary authorities have great responsibility in terms of anticipating the expectations and reactions of economic entities in terms of the measures taken by the monetary policy. It is an extremely complex and complicated process, bearing in mind that one can not only observe the achievement of the set internal target to the detriment of undermining the external imbalance, and vice versa. There is no single monetary policy that would give the same effects in all countries that apply it. It is therefore not surprising that in the previous period, the monetary authority in Serbia applied several different monetary policy regimes, which carried with them different primary goals and instruments for their realisation. The implementation of different regimes is due to the changing circumstances and factors in the domestic economy, as well as the situation in the world economy. Problems are particularly evident in underdeveloped, transit economies, although further use of this term is debatable. The transition implies moving from one state of the economy to another that is timelimited. Considering the length of this transition period in undeveloped countries, even in Serbia, it takes form of permanence more than a transient phase. Nevertheless, in such economies, the inconsistency in defining the primary goals and the use of monetary policy instruments for their 
realisation may be a major problem in achieving the positive effects of using it. But given the fact that the application of monetary policy is conditioned by the state of the economy, which is constantly changing in the transit period, then its constant change is not surprising, as a result of the devaluation of the effects that should have been achieved. The paper will discuss the theoretical considerations of the basic monetary policy regimes defined by the International Monetary Fund (IMF), the monetary policy of the European Union (EU), monetary policy in Serbia, achieving numerical values of macroeconomic indicators as a prerequisite for successful EU membership.

\section{Monetary policy regimes}

According to the IMF classification (IMF, De Facto Classification of Exchange Rate Regimes and Monetary Policy Frameworks, 2008), monetary policy regimes are:

- exchange rate anchor,

- monetary aggregate target,

- inflation targeting framework and

- $\quad$ other (monetary policy with implicit but not explicit anchor).

Considering the importance of certain monetary policy regimes and the frequency of their application in different countries, the theoretical bases of the first three regimes will be explained in more details below.

\section{. Exchange rate anchor}

The exchange rate anchor regime is one of the most frequently used strategies in the transition period, with the exchange rate being used as a nominal anchor. Targeting the exchange rate implies the fixed value of the local currency in relation to the currency of an anchor country, i.e. low inflation countries such as the US or EMU. This monetary policy regime can not be applied in all countries, because for some of them there is no country whose currency could serve as a nominal anchor (US, Japan or the European Monetary Union). Mishkin (Mishkin, 2000, p. 9) points out that the use of the exchange rate as a nominal anchor contributes to inflation control, linking the domestic prices of internationally tradable goods with the prices of these goods in the nominal anchor country, alleviating and completely eliminating inert components of inflation spreading into wages and prices of goods that are not the subject of international exchange, and directs inflationary expectations towards those in the country of the nominal anchor. Another advantage is that it contributes to the reduction and final elimination of the currency risk component of the domestic interest rate, reducing the costs of the government and the private sector, and improving the prospects for investment, financial deepening and economic growth. As an additional advantage of the implementation of this monetary policy regimen is that it is clear, simple and understandable to the public. On the other hand, as the main disadvantages of this regime, Mishkin points out the loss of independence in the implementation of monetary policy, the restriction of the money supply level in the country by the growth of the money supply in a country whose currency serves as a nominal anchor, and its application gives space for various types of speculative activities. 


\section{. Monetary aggregate target}

Monetary aggregate target involves the use of monetary aggregates as an intermediate goal, through which it influences the achievement of the highly defined monetary policy goal. The basis for the transition to this regime was in the need to reorient the monetary policy following the breakdown of the Bretton Woods system. Moving from fixed to flexible exchange rate gave the central bank the ability to control the amount of money and credit expansion, rather than maintaining the stability of the exchange rate against the US dollar. Fridman (Friedman, 1953, p. 200 ) argued in the 1950s that a constant monetary growth rate (as an intermediate target) of 3$5 \%$ per annum is required for price stability. Monetary targeting is questioned when it is established that there is no stable relationship between the amount of money and inflation and that the function of money demand is not stable, as confirmed by changes in monetary aggregates. This has caused problems in developed countries to maintain monetary stability through interest rates, and in countries with non-convertible currencies through a fixed exchange rate policy. Nevertheless, according to the 2012 IMF data, 29 countries use this monetary policy regime.

\section{Inflation targeting framework}

Targeting inflation is the "youngest" monetary policy regime, first applied in 1990 in New Zealand. However, as early as next year, Canada begins to apply this regime, in 1992, the United Kingdom, and in 1993 Sweden and Finland. Then, Australia and Spain (1994) went through the same regime, followed by Israel, Brazil and Chile, and today, according to the 2012 IMF, it is applied to 32 countries. The main elements of this regime are: the need to publicise a mediumterm inflation target; the obligation to define price stability as a primary goal of monetary policy; full information about all the variables used in making decisions, and not only monetary aggregates; transparency of the monetary policy strategy and growth of the central bank's responsibility for achieving the primary goal. Misconceptions related to this monetary policy regime could be reduced to the following. First, as Mishkin (Mishkin, 2001) points out, inflation targeting is a framework for monetary policy, not a rule. Every monetary policy, if it seeks to be coherent and purposeful, is placed in some conceptual frameworks, and it is just the question of how much that concept is clearly defined. According to Bernanke (Bernanke, 2003) inflationary targeting provides a single, coherent framework for thinking about monetary policy choices, with the involvement of the public. If, in this context, monetary policy succeeds in achieving the goals of directing inflationary expectations, the achievement of the ultimate goals is significantly facilitated. Another misconception concerns the assumption that inflationary targeting is exclusively based on inflation control, ignoring the goals of growth and employment. And as the last misconception that Bernanke points out, it refers to the assumption that inflation targeting is not consistent with the central bank's commitment to maintaining financial stability (the US example).

\section{The single monetary policy of European Union}

The primary objective of the European System of Central Banks shall be to maintain price stability (Article 127 of the Treaty on the Functioning of the European Union) within 18 countries as a members of European Monetary Union. The European Central Bank found the solution in the following: the ultimate goal, defined as price stability, i.e. the annual growth of the 
Harmonised Consumer Price Index to $2 \%$ to be achieved over two bases. The first is monetary on the assumption that GDP growth will be around $2 \%$ per annum, a $0.5 \%$ decrease in the money circulation, that the growth in prices will follow inflation growth of $2 \%$, the growth of monetary aggregate M3 of $4.5 \%$ is planned (at the basis of the quantitative money equation). If the observed monetary aggregate $\mathrm{M} 3$ at some point exceeded the given amount, it would be a sign for the ECB that through instruments, that is, the level of short-term interest rate, it would reduce the amount of money and bring it into the planned growth frames. Another basis for influencing the achievement of the ultimate goal is the large number of indicators of future price movements, which are the level of wages, the price of bonds, the exchange rate, the fiscal policy i.e. its indicators. Of all these variables, the monetary aggregate M3 has the greatest impact on the level of inflation in the future. The ECB was formed following the model of German central bank, and some recent studies show that the Bundesbank's strategy was closer to inflationary targeting, as it "targeted" through a cash-set that was established on the basis of reliable inflation data i.e. it carried out inflation targeting until the cash stock was out of the target band. In fact, this meant that the goal was defined through a monetary outcome, rather than an instrument or an intermediate variable, and that it did not acquire its reputation because it targeted money, rather than keeping its inflation level at a very low level. (Un) Success in achieving the set goal is shown in the following graphic.

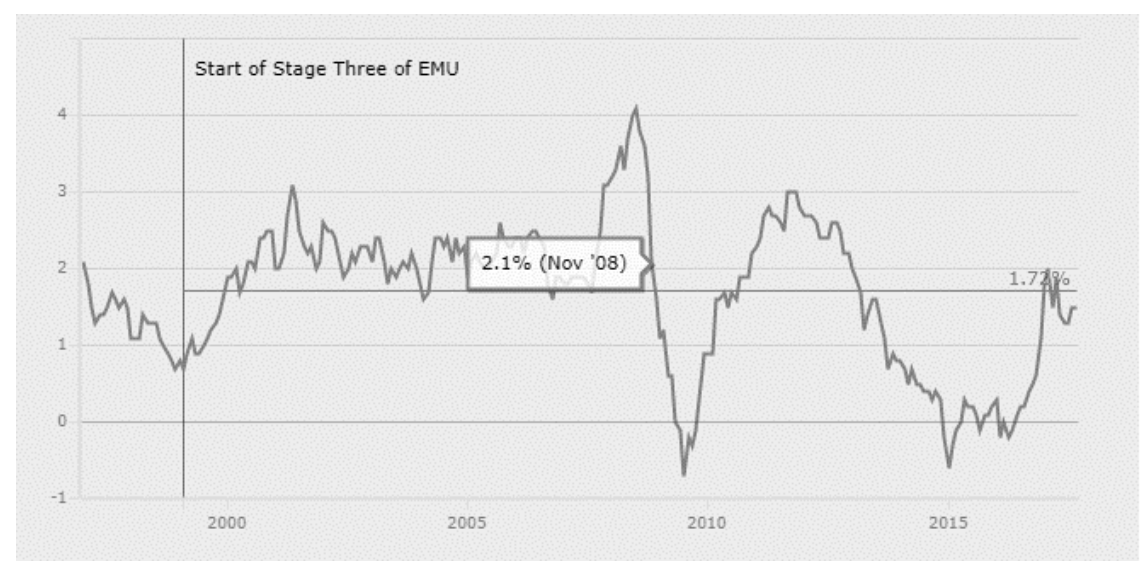

Fig 1: Inflation in the euro area (annual percentage changes, non-seasonally adjusted) (Eurostat. Data prior to 1996 are estimated on the basis of non-harmonised national Consumer Price Index (CPIs). Average inflation since 1999.)

\section{Monetary policy in Republic of Serbia}

In the search for an optimal monetary strategy, after the negative experiences on the level of the inflation rate with the exchange rate as a nominal anchor, the National Bank of Serbia used different monetary policy regimes from 2000 to 2006, which are given in the following table. 
Table 1: Monetary Policy Regimes in Serbia (Customised according to NBS data)

\begin{tabular}{|c|c|c|c|c|}
\hline $\begin{array}{l}\text { Monetary policy } \\
\text { regime }\end{array}$ & $\begin{array}{l}\text { Operational } \\
\text { target }\end{array}$ & $\begin{array}{l}\text { Exchange } \\
\text { rate regime }\end{array}$ & $\begin{array}{l}\text { Monetary policy } \\
\text { instruments }\end{array}$ & $\begin{array}{l}\text { Capital } \\
\text { control }\end{array}$ \\
\hline $\begin{array}{l}\text { Monetary } \\
\text { aggregate target } \\
(2000-2006)\end{array}$ & $\begin{array}{l}\text { Net domestic } \\
\text { assets (ceiling) } \\
\text { Net assets } \\
\text { (under) }\end{array}$ & $\begin{array}{l}\text { Managed } \\
\text { floating }\end{array}$ & $\begin{array}{l}\text { Interventions in the } \\
\text { foreign exchange } \\
\text { market, the reserve } \\
\text { requirement rate, } \\
\begin{array}{lr}\text { open } & \text { market } \\
\text { operations } & \end{array}\end{array}$ & $\begin{array}{l}\text { In a short } \\
\text { time }\end{array}$ \\
\hline $\begin{array}{l}\text { Inflation targeting } \\
(\text { from } \\
\text { (period 2009) } \\
2007-2009 \text { from } \\
\text { preparation for } \\
\text { direct inflation } \\
\text { targeting } \\
\text { framework) }\end{array}$ & $\begin{array}{l}\text { Short-term } \\
\text { interest rates }\end{array}$ & $\begin{array}{l}\text { Managed } \\
\text { floating, with } \\
\text { a tendency to } \\
\text { free } \\
\text { fluctuation }\end{array}$ & $\begin{array}{l}\text { Basic instrument - } \\
\text { two-week repo rate; } \\
\text { auxiliary- } \\
\text { intervention in the } \\
\text { foreign exchange } \\
\text { market, prudential } \\
\text { measures, the reserve } \\
\text { requirement rate }\end{array}$ & $\begin{array}{l}\text { In a short } \\
\text { time }\end{array}$ \\
\hline
\end{tabular}

The implementation of the new monetary policy regime has yielded good results in terms of reducing inflation to the target level. From inflationary targets in the range of $8-12 \%$ in 2009, the target for 2017 is $3+-1.5$ p.p. Key Policy Rate Cut to $3.5 \%$ in October 2017, from $17.75 \%$ in 2008. Bearing in mind the achieved results, it can be said that the new monetary policy regime has contributed to the stabilisation of internal economic flows in Serbia. GDP per capita shows a growth trend in the observed period (5206.25\$ in 2006, to $5852.08 \$$ in 2016).

Based on the analysis of the data for 40 countries, which were used to identify the key economic indicators, whose numerical value can serve as the indicator of the optimal moment of accession, the values of the GDP per capita (measured in purchasing power parity) of 17950 US dollars has been obtained. Although the value of the GDP per capita in Serbia is still far from this level, the obtained values should indicate the importance of continuing the necessary structural reforms to achieve higher growth rates of GDP. By applying the regression analysis, it is estimated that Serbia, if the current upward trend of development continues, will reach this value in 2026. (Šabotić, Marinković, Banković, 2016, p.199).

\section{Conclusion}

Although it is not possible to isolate only the impact of the application of different monetary policy policies on macroeconomic indicators and the achieved results in Serbia, the experience so far has shown that consistency in implementation of selected regime is very important. Since inflation targeting as a regime has been in the practice for 8 years in Serbia, it has given good results in terms of stabilising inflation and reducing it to selected framework. If it continues with the implementation of monetary policy in the same direction (without major external shocks), best time for accession to the EU for Serbia is 2026. with the entry to the EU, the transition toward the target zone ERM II will be more smooth, with less shocks concerning internal and 
external balance. Current monetary and exchange rate regimes offer monetary authorities in Serbia more discretionary space having in mind the decision whether to influence the exchange rate fluctuations and in what way - indirectly via interest rate or directly through foreign exchange interventions.

\section{References}

1. Agénor, P., Orderly Exits from Adjustable Pegs and Exchange Rate Bands, Policy Reform, (2004) 7(2): 83-108

2. Allegret, J., Which Currency Exchange Regime for Emerging Markets? Corner Solutions Under Question, Panoeconomicus, (2007) 54(4): 397-427

3. Bernanke B., A Perspective on Inflation Targeting, At the Annual Washington Policy Conference of of the National Association of Business Economists, Washington, (2003) http://www.federalreserve.gov/BoardDocs/Speeches/2003/20030325/default.htm.

4. Friedman, M. The case for flexible exchange rates. In M. Friedman (ed.) Essays in Positive Economics Chicago: University of Chicago Press, (1953) pp. 157-203

5. International Monetary Fund, De Facto Classification of Exchange Rate Regimes and Monetary Policy Frameworks, 2009,

http://www.imf.org/external/np/mfd/er/2008/eng/0408.htm (accessed February 30, 2017)

6. Josifidis, K., Allegret J.,Beker-Pucar, E., Monetary and Exchange Rate Regimes Changes: The Cases of Poland, Czech Republic, Slovakia and Republic of Serbia, PANOECONOMICUS, (2009) pp. 199-226

7. Mishkin F., Inflation targeting in emerging market countries, NBER, WP 7618, (2000) pp. $1-12$.

8. Mishkin F., Monetary Policy Strategies for Emerging Market Countries: Case Studies from Latin America, in Current Issues in Emerging Market Economies, (2001) pp. 1-35.

9. National Bank of Serbia. 2008a. Memorandum of the National Bank of Serbia on Inflation Targeting as Monetary Strategy.

http://www.nbs.rs/export/internet/english/30/Memorandum_monetarna strategija_122008_eng.pdf

10. Šabotić, Z., Marinković, S., Banković D., Quantifying the economic parameters as indicators od Serbia's accession to the European Union, Teme, (2016) XXXX (1): $187-$ 202 